\title{
Analysis on China's Ecological Compensation Mechanism and Its Policy Choice
}

\author{
Zhigang Wang \\ Zhuhai College of Jilin University \\ Zhuhai, China 519041
}

\begin{abstract}
In recent years, ecological pollution problems in China are becoming more and more prominent, and it is imperative to build an efficient ecological compensation mechanism. At present, China has internalized the external cost of environment pollution through taxation, ecological charge and some other approaches; in terms of fiscal expenditure, producers and protectors of ecological products are compensated through transfer payments and tax expenditures. Although these systems are conducive to environmental protection, they are not yet perfect. With regard to the construction of ecological compensation mechanism, Europe and the United States have a lot of valuable experience. Based on this, China can put forward relevant policies to improve the ecological compensation mechanism. In the field of agriculture and mining, the basic principle of "who destroys and who recovers" should be emphasized, and the incentive and restraint mechanism of ecological protection should be established; in the field of ecological compensation method, while emphasizing government leadership, it should also introduce market-based means to optimize resource allocation through a combination of government and markets; in terms of policies and laws, relevant policies and laws should be promulgated on the basis of ecological projects, and a policy and legal system should be constructed according to local conditions to improve the flexibility and adaptability of ecological compensation mechanism.
\end{abstract}

\section{Keywords-China; ecological compensation; policy choice}

\section{INTRODUCTION}

Ecological environment is the important support and guarantee for the sustainable development of human society and an important material basis for the national economy and people's livelihood. After more than 30 years of sustained development, China has achieved a series of major economic and social achievements, but at the same time, it is also facing major problems of depletion of resources and ecological deterioration. In order to solve these problems, China urgently needs to establish and improve ecological compensation mechanism to achieve a virtuous circle of environmental protection, and lay a foundation for regional economic restructuring and upgrading, and healthy economic and social development. The key point of the ecological compensation is to internalize the external cost of the ecological destruction, that is the problem of "who pollutes, who pays", "who destroys and who recovers". Finally, the interests of the producers and protectors of ecological products are respected and compensated. Because the ecological compensation mechanism has a strong public nature and involves the interests of the general public, the establishment of an ecological compensation mechanism cannot rely solely on the market, and it needs more support from the national policy level. In order to protect the ecological environment, the 19th National Congress report has listed the establishment of an ecological compensation mechanism as one of the important tasks of "speeding up the construction of an ecological civilization system and building a beautiful China". This also reflects the importance and urgent need for China to establish and improve ecological compensation mechanism. Under such circumstances, how to use policy to promote ecological compensation work is of great significance to healthy development of the current economy and society.

\section{ANALYSIS OF CHINA'S ECOLOGICAL COMPENSATION MECHANISM}

At present, Chinese government attaches great importance to the construction of ecological compensation mechanism, and actively promotes the ecological compensation mechanism based on government financial support and ecological economic value. Generally speaking, ecological compensation mechanism cannot separate from the strong support of government financial funds, which can be examined from both fiscal revenue and fiscal expenditure.

\section{A. Fiscal Revenue}

First of all, various taxes are one of the important sources of ecological compensation funds. In 2011, China began to implement resource tax reform across the country, including the mining of coking coal, rare earths, and other minerals into the scope of taxation. At the same time, it delegated the original ore taxation rights of non-ferrous ore and non-metallic ore mines to local governments and strengthened the protection of mineral resources. Except for resources tax, farmland occupancy tax, urban construction land use construction, consumption tax on some resource products, vehicle and vessel use tax and other taxes, all of them show strong environmental protection demand, which has a strong promoting effect on ecological compensation and environmental pollution control.

Secondly, environmental recovery governance deposit is also a financial guarantee for ecological compensation. In 2006, the Ministry of Finance, the State Environmental Protection 
Administration and other departments released Guiding Opinions on Gradually Establishing Mine Environmental Management and Ecological Restoration Responsibility Mechanism, which requires that all regions strictly supervise the enterprises the extraction of mining environment restoration and recovery control deposits according to regulations and establish a margin account in designated banks of local governments to ensure that special funds are used for ecological management and environmental protection; in 2009, The Ministry of Land and Resources promulgated and implemented Mine Geological Environmental Protection Regulations, which requires that the enterprise shall, when applying for a mining license, formulate a mining environment restoration and management plan and sign the pledge to pay the environmental restoration and management deposit. So far, most provinces in the whole country have implemented the environmental restoration management margin system.

Finally, ecological compensation fee is the earliest financial means of ecological compensation in China. Since 1980s, China has established a systematic ecological compensation system: first, penalty charges for externalities, which mainly aim at sewage charges for sewage, waste gas, solid waste, and hazardous waste, excessive discharge of noise, charges of marine debris detection, and waste dumping. Second, charges for paid use of economic resources, which mainly aim at charges for the reclamation of cultivated land, compensation for mineral resources, fees for sand and gravel resources of the Yangtze River, and fees for water resources. Third, charges for the maintenance and reconstruction of the ecological environment, which aim at charges for land reclamation, woodland compensation, soil erosion control, urban sewage treatment, various kinds of wildlife resources protection and so on.

\section{B. Fiscal Expenditure}

First, transfer payments. Ecological compensation transfer can be divided into horizontal transfer payment and vertical transfer payment. Horizontal transfer payment refers to transfer of funds between governments at the same level within and outside the ecological protection zone. Vertical transfer payment refers to the four levels of government at the central, provincial, city and county levels, from top to bottom. At present, China is significantly more vertical than horizontal in the ecosystem transfer payment system. Among the vertical transfer payments, several of the central government's transfer payments to local governments are the largest and the most extensive. For example, among the central special ecological compensation transfer payments, there are the Central Forest Ecological Benefit Compensation Fund, the Grassland Ecological Protection Subsidy Grant Fund, the Mine Geological Environment Restoration and Recovery Fund, and the National Soil and Water Conservation Key Construction Project Grant Special Funds, etc. Among the central general transfer payments, there are resource-exhausted urban transfer payments, which are mainly used for the development transformation and public service support of 69 resourceexhausted cities across the country; there are also key ecological function area transfer payments, which are mainly used in key ecological function areas such as the Sanjiangyuan
Nature Reserve and the Middle Line South-to-North Water Transfer Water Conservation Area.

In terms of horizontal transfer payments, it is mainly reflected in the watersheds in the provinces of various provinces. The area of compensation is determined according to the water quality of the river's out-of-bounds section. When the water quality of the section is poor, the upstream area compensates the downstream area; while the water quality of the section is good, the downstream area will compensate the upstream area. The calculation of compensation funds is usually based on indicators such as the degree of cross-section water quality exceeding the standard and the concentration of cross-section pollutants. Once the amount of funds is determined, it will be unified withheld by the provincial finance, and then the provincial finance will use subsidy and reward to provide uniform compensation, adopting a system of mutual compensation and punishment. Compared with the transfer payment of ecological compensation between upstream and downstream cities in the province, the horizontal transfer payment between provinces is still relatively rare. In 2010, China has established joint air defense and joint prevention and control mechanisms in the Yangtze River Delta, the Pearl River Delta and the Beijing-Tianjin-Hebei region, and promoted the ecological compensation cooperation mechanism among the provinces in the middle reaches of the Yangtze River. But it is still limited to inter-provincial cooperation in ecological management and compensation, and does not involve transfer of financial resources between provincial governments.

Secondly, tax preference. Taxes are an important means for the state to regulate and control the economy, and tax preference policies can also be used for ecological compensation. In fact, the government's tax preference policies will lead to a reduction in fiscal revenue. This can be understood as a kind of "fiscal expenditure", that is, "tax expenditure", which is also a type of ecological compensation for transfer payments. At present, there are 15 kinds of taxes in China, many of which are related to tax preference policies and ecological compensation. For example, in the consumption tax, low tax rates apply to high quality oil products and small displacement motor vehicles; in VAT, the policy of exemption, reduction or refund of resources recycling is implemented; in the land use tax, exemption policies are applied to various nature reserves and major forest parks; in the corporate income tax, corporate income tax is levied on income reduction of certain environmental protection projects and energy saving and emission reduction projects of the enterprise; in the vehicle and vessel use tax, the exemption policies of those new energy vehicles and low-energy vehicles are implemented.

\section{HiSTORICAL PRACTICE OF FOREIGN ECOLOGICAL COMPENSATION MECHANISM}

\section{A. European Ecological Compensation Mechanism}

As a developed region in the world, Europe has experienced rapid industrialization and urbanization. The increase of productivity has led to a decline in the production surplus of agricultural products and the comprehensive comparative benefit of agriculture. In order to avoid these 
cases, most countries in the Europe have published the policy of returning farmland to forests and grasslands in agriculture and for those who are willing to return their agricultural land to forest; the government will give a certain amount of compensation and reward. For example, in UK, the government stipulates that farmers who are willing to return farmland to forests can receive a compensation of no more than 125 pounds per hectare from the government each year after signing the agroforestry agreement, which can be held for 30 years. In Switzerland, federal laws provide financial compensation for ecological organic agriculture and species conservation activities that are conducive to environmental protection. The government has formulated a regional plan for ecological compensation regional plan and an ecological tax reform plan, focusing on rewarding and compensating farmers who actively promote the development of ecological organic agriculture and protect ecological balance. In addition, in the field of mineral resources development, Europe also actively implements the ecological compensation mechanism. For example, in German, government actively promotes the reclamation of abandoned old mining areas, which are mainly financed by the government, with $75 \%$ of the federal government and $25 \%$ of the state government. Meanwhile, in the Germany laws, it is regulated that mining enterprises must extract $3 \%$ of their annual profits as a special fund for reclamation in the future. For those natural resources such as forests that have been damaged by mining, they must ensure that they recover in other areas.

\section{B. American Ecological Compensation Mechanism}

In the 1970s, the United States has implemented the emission trading system and established a complete emissions trading system with bubbles, compensation, bank, and capacity savings as the main contents, which significantly improved the environmental economic benefits. Meanwhile, the United States has also introduced compensation mechanism for soil and water, which stipulates government and residents in the downstream benefit area for water and soil are obliged to make monetary compensation to institutions and individuals who contribute to the upstream region. In the field of agriculture, the United States has implemented a voluntary program of reforestation in 1956, which led some farmers to return farmland to forest and grassland by means of compensation. In 1985, the United States implemented a special protection plan, and it planned to implement the return of farmland and fallow cultivation in areas prone to soil and water loss. In this regard, the U.S. government needs to provide a one-time payment of $50 \%$ of its planting income to farmers who have permanently retired farmland, besides, the U.S. government also needs to give a certain amount of compensation each year. In the field of mining resources development, U.S. laws stipulate that the principle of "who destroys and who recovers" shall be applied to the ecological problems caused by the mining area, and the mining company shall take full responsibility. Meanwhile, the United States also implements a license management system for mining areas and collects deposits for rehabilitation of mining areas. After the enterprises have effectively fulfilled their responsibilities for the ecological restoration of the mining area, they will be returned. If the mining organization fails to complete the ecological restoration of the mining area, the deposit will be used to finance the third Party of ecological restoration.

\section{SElECtion OF ECOLOGICAL COMPENSATION POLICY BASED ON FOREIGN EXPERIENCE}

\section{A. Selection of Ecological Compensation Policy of Agriculture}

According to foreign experience, the ecological compensation mechanism of agriculture has the following characteristics: first, whether farmers are willing to cooperate with government, and the key to adopting environmentally friendly production methods is whether the government can continue to invest in agriculture for a long period of time; second, the main method of agricultural subsided is the price subsidy mechanism, that is, directly subsidizes the price of agricultural products produced by farmers. The subsidy also emphasizes the consistency of rights, responsibilities, and benefits, and uses strict constraint mechanisms to ensure the realization of ecological compensation targets. In the United States, the government has published "protection plan" based on the ecological compensation of agriculture. If the farmers in the area are not willing to cooperate, the government will eliminate agricultural support policies enjoyed by farmers. After the protection period, if farmers would like to replant crops on fallow land, they must strictly abide the related provisions on the protection of cultivated land, or they will be severely punished by the government. Third, implement the guide of national plans based on respecting the individual willingness of farmers.

In terms of ecological compensation systems implementing in China, the main reference significance is: first, in order to guarantee the effectiveness of the ecological compensation policy, it is necessary to establish and complete a strict responsibility and restraint mechanism for ecological construction and protection. This is a basic prerequisite for the smooth implementation of the ecological compensation policy; second, only the constraint mechanism is far from enough. It must also have sufficient and long-lasting direct economic compensation. This is an important incentive for ecological and environmental protection. It can enable the economic entities to actively participate in the ecological compensation program; third, for developing countries with severely unbalanced regional economic development, the implementation of the ecological compensation mechanism must consider the balance between the government's public services and financial capabilities, and the standards and levels of compensation among different regions should be differentiated so that ecological compensation can be achieved within their capabilities. Fourth, in the process of formulating ecological compensation policies, it is necessary to enhance the degree of participation of all parties, respect the opinions of various parties, and especially respect the legitimate demands of local residents.

\section{B. Selection of Ecological Compensation Policies for Natural Resources Development}

In the process of natural resources development, the problem of ecological destruction is very serious. Countries 
around the world have formulated ecological compensation policies for the development of resources to protect the environment. Most of these policies emphasize the main body of corporate responsibility in the process of environmental protection and ecological restoration, and also consider relevant responsibilities of enterprises are legally time-limited, so as to implement different differentiation policies for old and new mining area. Under normal circumstances, the historical problems of the old mining areas mainly rely on the government funds to solve the problem of ecological compensation; for the problem of ecological destruction in new mining areas, the basic principle of "who destroys and who recovers" is emphasized. The primary responsibility shall be undertaken by the developer of natural resources, who is also responsible for the ecological restoration tasks in the process of resources development and after the process of resource development. These above successful experience can be directly referred by China.

\section{Selection of Ecological Compensation Methods}

There are various ecological compensation methods of different countries around the world, but they are generally similar, that is, most of them solve ecological compensation problems by purchasing ecosystem services. From the historical experience, the purchase of ecosystem services can be divided into two types of government fiscal payment and market payment. At present, market payment has become increasingly the main method of purchase. As for China, government has been the leader of the construction and completion for ecological compensation mechanism in the past and will do so in the future. In this process, on the one hand, government is the main body of payment for ecological compensation mechanism, providing adequate financial support for the suppliers of ecological services; on the other hand, the government also establishes and promotes market mechanisms, uses market methods to solve ecological compensation issues, is responsible for measuring, supervising and certificating of ecological service, and provide technical and management support to ecological services. At present, the Chinese government should further promote the role of the market in ecological compensation, actively explore and implement an ecological services monitoring system, formulate rules for the market transactions of ecological services, promote the standardized operation of the ecological services market, and continue to improve the market mechanism of ecological compensation and realize the combination of government and market, comprehensive allocation of resources.

\section{Selection of Related Policies and Laws of Ecological Compensation}

First of all, it is an important guarantee for the smooth implementation of ecological compensation to introduce relevant policies and laws on the basis of ecological projects. In the process of establishing and completing ecological compensation mechanism, China must give full play to the role of legislature, formulate policies and laws around ecological compensation mechanisms, implement the basic principles of ecological compensation in the framework of policies and laws, and further promote the importance of the compensation mechanism, which shall be treated as a national strategic task, and strengthen its operability; In the process of implementing relevant policies and laws, China must also scientifically design ecological projects and closely monitor the operation of ecological projects so as to ensure that ecological projects can achieve ecological compensation benefits in the greatest degree.

Secondly, it is necessary to further improve the adaptability of legal system of ecological compensation policy, which is an indispensable part of the ecological compensation process. In the process of establishing and improving the ecological compensation mechanism, we must attach great importance to the feasibility and adaptability of the policy and legal system, strive to coordinate the conflicts between various policies and laws, and in particular integrate and implement the different policies and regulations stipulated by various central and local departments. For those institutional arrangements that are not conducive to the use of ecological compensation mechanisms, we must make great efforts to sort out and rectify. Meanwhile, we should streamline administration and delegate power. In the process of implementing the ecological compensation mechanism, the local government should be given the responsibility of the main body position, so that it has a certain decision-making space. It should formulate specific policies conducive to local ecological protection in light of local conditions and avoid the nationwide "one size fits all" approach.

\section{CONCLUSION}

From the historical perspective, ecological environment pollution is a problem must be solved in the process of country's economic development, and one of the effective solution is to build scientific and reasonable ecological compensation mechanism, through the way of the internalization of external cost, it will be paid by polluter and benefit the protector, and this is the common practice around the world, from the actual situation of countries, the establishment of ecological compensation mechanism and operation have been affirmed, good results have been achieved.

As a developed economy, Europe and the United States have made a series of achievements in the construction of ecological compensation mechanisms and have a strong reference for China's current ecological compensation mechanism. On this basis, China can build ecological compensation mechanisms with Chinese characteristics in accordance with its own national conditions. For example, in agriculture, forestry, mining, etc., financial subsidies, environmental recovery and treatment guarantees, and ecological compensation fees can be used to encourage stakeholders to reduce external actions, and strengthen environmental protection awareness. Meanwhile, it should also adopt a diversified ecological compensation approach. It can neither rely on the government too much, nor can it be fully handed over to the market. An ecological compensation system that combines government payments and market payments should be constructed to promote standardized operation of the service market of the ecological compensation system while the government plays a guiding role, continuous improve the market-based mechanism of ecological 
compensation, combine it with government regulation, and improve resource allocation efficiency. In addition, the establishment and implementation of the ecological compensation mechanism must be accompanied by relevant policies and laws. China must play the role of the legislature, implement the basic principles of the ecological compensation mechanism in the legal framework, and ensure the mandatory and authority of the ecological compensation mechanism; meanwhile it is also necessary to streamline administration and delegate power, formulate relevant legal systems suitable for different regions according to local conditions, and avoid arbitrary approach of "one size fits all" in the whole country, so as to make the ecological compensation mechanism flexible and better serve the economic and social development.

\section{REFERENCES}

[1] Lu Hongyou, Du Yixuan, Qi Yu. Study on the fiscal policy of ecological compensation [J]. Environment Protection, 2014 (5) . 卢洪 友, 杜亦譞, 祁毓.生态补偿的财政政策研究[J].环境保护, 2014 (5).

[2] Peng Chunning. On the financial transfer payment of ecological compensation mechanism [J]. Jianghan BBS, 2009 (3). 彭春凝. 论生态 补偿机制的财政转移支付[J].江汉论坛, 2009 (3).

[3] Zhang Yongping. Research on establishing ecological compensation mechanism for fiscal policy [J]. China's land and resources economy, 2007 (8) 张永平.建立生态补偿机制的财政政策研究 [J].中国国土资 源经济, 2007 (8)

[4] Kong Zhifeng. Financial Policy Design of Ecological Compensation Mechanism [J]. Finance and Development, 2007, (2). 孔志峰.生态补偿 机制的财政政策设计 [J].财政与发展，2007（2）.

[5] Ouyang Zhiyun, Zheng Hua, Yue Ping. Ideas and Measures for Establishing Ecological Compensation Mechanism in China [J]. Chinese Journal of Ecology, 2013 (03). 欧阳志云, 郑华, 岳平.建立 我国生态补偿机制的思路与措施 [J].生态学报, 2013 (03).

[6] Wang Defan. Study on the theory and countermeasure of lateral transfer payment system based on regional ecological compensation mechanism [J]. East China Economic Management, 2018 (01). 王德凡. 基于区域 生态补偿机制的横向转移支付制度理论与对策研究[J].华东经济管 理, 2018 (01). 